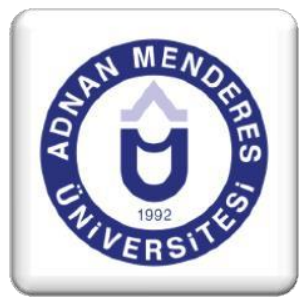

\title{
İnşaat İşletmelerinin Maliyet Yönetiminden Beklentileri: Türkiye Uygulaması ${ }^{1}$
}

\author{
Fatma İZMIRLİ ATA ${ }^{2}$ Semra ÖNCت̈ ${ }^{3}$
}

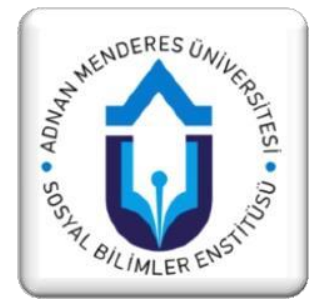

\section{ÖZET}

Yoğun rekabet ortamında başarılı olmak isteyen işletmeler için "müşteri isteklerini en düşük maliyetle, istenilen zaman ve kalitede" karşılamak zorunlu hale gelmiştir. Bu zorunluluğu aşmak isteyen işletmeler için kendilerinin kontrol edebildikleri, yönetebildikleri maliyetlerin önemi artmış, ihtiyaç duyulan maliyet bilgilerini sağlayan, maliyetleri planlamaya yarayan stratejik maliyet yönetimi uygulanmaya başlanmıştır. Stratejik maliyet yönetimi ile dış çevreden ve finansal muhasebe sisteminden tüm stratejik kararlara ilişkin bilgiler alınarak bu bilgiler bir arada kullanılmaya başlanmıştır. İşletmeler bu amaçla çeşitli stratejik maliyet yönetimi teknikleri geliştirmişlerdir.

Bu çalışmada Türkiye'de faaliyet gösteren inşaat işletmeleri ile anket çalışması gerçekleştirilmiş ve elde edilen sonuçlar sayesinde bu işletmelerin maliyet yönetimi kapsamında gerçekleştirdikleri faaliyetlerin ve beklentilerinin neler olduğunun ortaya konması amaçlanmıştır. Gerçekleştirilen çalışma sonucunda işletmelerin sektörde var olan yoğun rekabet nedeniyle maliyet yönetimine odaklandıkları, bu sürece tedarikçi, alt yüklenicileri ve işletme çalışanlarını da dahil ettikleri ve maliyet düşürme çabalarına henüz proje aşamasında odaklandıkları belirlenmiştir.

Anahtar Kelimeler: İnşaat İşletmeleri, Maliyet Yönetimi, Üretim, Muhasebe

Jel Sinıflandırmasi: D24, L74, M40, M41

\section{Expectations of Construction Enterprises from Cost Management: Turkey Implementation}

\begin{abstract}
In order to be successful in an intense competition environment, businesses must meet with customer desires with the lowest cost and optimum time and quality. For companies which want to overcome these requirements began to give more importance to the costs that they can manage and control. They start to implement strategic cost management to provide required information and cost planning. With strategic cost management all information are taken from the external environment and financial accounting system for strategic decision making and these have been started to use together. For this purpose various strategic cost management techniques have been developed.
\end{abstract}

In this study, a survey was carried out by construction enterprises operating in Turkey and with these results we aimed to reveal what are the expectations and actions of companies under the cost management. The results of this study show that companies focus on cost management due to the intense competition in construction sectors, they incorporate suppliers and subcontractors to this process and companies focused cost reduction efforts on the design stage yet.

Keywords: Construction Enterprises, Cost management, Production, Accounting

Jel Classification: D24, L74, M40, M41

${ }^{1} \mathrm{Bu}$ çalışma Arş. Gör. Fatma İZMİRLİ ATA' nın, "Hedef Maliyetleme ve İnşaat İşletmelerinde Uygulanabilirliğinin Analizi” adlı doktora tez çalışmasından üretilmiştir.

${ }^{2}$ Yrd. Doç. Dr., Manisa Celal Bayar Üniversitesi, İktisadi İdari Bilimler Fakültesi, İşletme Bölümü, MuhasebeFinansman ABD

${ }^{3}$ Prof. Dr., Manisa Celal Bayar Üniversitesi, İktisadi İdari Bilimler Fakültesi, İşletme Bölümü, MuhasebeFinansman ABD 


\section{Giriş}

Teknolojik alanda ortaya çıkan yenilikler, iş çevrelerinin hızla değişmesine, üretim süreçlerinin yenilenmesine, üretim miktarlarının artmasına, müşterilerin beklenti ve isteklerinin ön plana çıkmasına, hata ve gecikmelerin affedilemez hale gelmesine ve rekabetin önündeki tüm engellerin ortadan kalkmasına yol açmıştır. Yeni oluşan bu ekonomik çevrede işletmeler, kontrolleri dışında olan fiyat ve müşteri beklentileri yerine, kendi üretim süreçlerini yenilemeye ve maliyetlerini düşürmeye odaklanmışlardır. $\mathrm{Bu}$ aşamada maliyetlere ait bilginin önemi artmış, maliyetlerin işletmelere rekabetçi avantaj sağlayacak şekilde işletme amaçları göz önünde bulundurularak stratejik bir şekilde yönetilmesine başlanmıştır.

İnşaat sektörünün yerli sanayiye dayalı olması, sağladığı yüksek istihdam, yan sanayileri destekleme gücü, döviz kazandırıcı niteliği nedeniyle ülkemiz ekonomisinde oldukça önemli bir sektördür. Bu çalışmanın amacı maliyet yönetiminin, dünyada sahip olduğu alt sektörler dolayısıyla lokomotif sektör olarak adlandırılan inşaat sektöründe uygulanabilirliğini ülkemiz açısından değerlendirmektir. $\mathrm{Bu}$ amaçla Türkiye İnşaat Sanayicileri İşveren Sendikası (İNTES), Türkiye İnşaat Malzemesi Sanayicileri Derneği (IMSAD) ve Borsa İstanbul (BİST) 100 endeksinde yer alan inşaat işletmeleri çalışmamızın ana kütlesi olarak belirlenmiştir. $\mathrm{Bu}$ işletmelerin araştırmanın ana kütlesini oluşturmasında diğer işletmelere göre daha büyük, kurumsallaşmış ve bilgilerine daha kolay ulaşılabilir olmaları rol oynamıştır. Konu ile ilgili literatür taraması yapılarak hazırlanan anket çalışması ile inşaat sektöründe rekabet seviyesi, pazar araştırmasına verilen önem, yeni projeler için maliyet belirleme teknikleri, işletmelerin alt yüklenicilerle olan ilişkileri, maliyet yönetiminden beklentileri ile maliyet yönetiminde zorlandıkları noktaların neler olduğu tanımlayıcı istatistikler yardımı ile ortaya konmaya çalışılacaktır.

\section{Maliyet Yönetimi}

Uzun vadede işletmelerin başarılı olabilmeleri için basit birtakım faktörleri en iyi şekilde yerine getirmeleri gerekir. Fonksiyonellik, maliyet, ürün geliştirme zamanı ve sunulan hizmetler bu faktörlerin önde gelenleridir (Sobotka ve Czarnigowska, 2007). Bu faktörlerden kalite, maliyet ve fonksiyonellik Cooper ve Slagmulder tarafından "hayatta kalmanın üç saç ayağı" (Survivaltripod) olarak adlandırılmıştır (Ibusuki ve Kaminski, 2007). İşletmeler için bu faktörleri kontrol altında tutabilmek ve yönetebilmek oldukça önemli bir hale gelmiştir. Ancak artan rekabet işletmelerin kalite, fonksiyonellik, sunulan hizmetler ve fonksiyonellik üzerindeki kontrolünü oldukça azaltmıştır. $\mathrm{Bu}$ noktada maliyet, ürünün başarısı için saldırganca yönetilebilecek bir alan olarak karşımıza çıkmıştır. Geleneksel maliyet muhasebesinden elde edilen bilgilerden daha kapsaml, daha esnek ve bazı durumlarda da tamamen farklı türden bilgi üreten ve daha az maliyetle daha fazla değer yaratan bir teknikler seti olan maliyet yönetimi yaklaşımı bu ihtiyacı karşılayabilmek için çalışmaktadır.

Üretilen ürünlerin maliyetini belirlemek, fiyatlama yapmak, maliyet unsurlarının kontrolü için bir standart oluşturmak ve ürün maliyetlerini sınıflandırmak gibi işlemlerden oluşan maliyet planlamasına ek olarak, son yıllarda yaşanan küresel rekabet baskısının ortaya çıkardığ 1 maliyet baskıları ile işletmeler maliyet oluşumunun geri planındaki nedenlerin analiz edilmesine ve maliyet oluşumunun hemen öncesinde maliyetleri kaynağında etkilemeye zorlanmışlardır (Alagöz ve Ceran, 2006).

Maliyet yönetimi, ürün maliyetlerini doğru olarak saptamak, işletmedeki işlemleri geliştirmek, israfi önlemek, maliyet etmenlerini tanımlamak, faaliyetleri planlamak ve 
işletmenin stratejilerini oluşturmak için faaliyetlerin yönetimi ve kontrolü olarak tanımlanmaktadır (Yüzbaşıŏlu, 2004; Brimson, 1991; Gündüz, 1997). Maliyet yönetimi, yönetim muhasebesinin bir biçimi olup, yakın zamanda yapılacak giderleri tahminlemeye dolayısıyla bütçenin aşılmasının önüne geçmeye çalışır (Karaa ve Geyikçi, 2015).

İşletmeler için doğru terim "maliyet azaltma" değil "maliyet yönetimi” olmalıdır. Çünkü maliyet azaltma ürünlerin kalite ve fonksiyonelliğinde azalmayı tanımlarken, asıl amaç daha kaliteli, tamamıyla aynı fonksiyonlara sahip fakat daha düşük fiyatlı ürün sağlamaktır (Ibusuki ve Kaminski, 2007).

Birim maliyetleri daha doğru hesaplama, maliyetlerin direkt izlenebilirliği konusunda yönetime katkı sağlama, maliyet etkinliği sağlama, maliyet raporları için gerekli bilgiyi sağlama, finansal olmayan göstergeleri ölçülebilir hale getirme, mamullerin yaşam dönemi performansının optimizasyonunda firmalara yardımcı olma, hangi faaliyetler maliyetleri yaratmakta ve hangi önlemlerle maliyetlerin düşürülebileceğini belirleme konusunda yardımcı olma, maliyet ve yönetim muhasebesi sistemlerinde basitleştirme, kolaylaştırma ve amaçlar doğrultusunda stratejilerle bütünleşmeyi sağlama maliyet yönetiminin işletmelere sağlayacağı yararlardır.

Maliyet yönetim sistemi ise, yöneticilerin kararlarını etkileyen maliyetlerle ilgili verilerin elde edilmesi ve bunların doğru analiz edilerek işletme amaçlarına uygun şekilde kullanılmas1 olarak tanımlanabilir (Barfield vd., 2000). Geleneksel maliyet sisteminde maliyetler katlanılması gereken unsurlar olarak algılanıp maliyetler ortaya çıktıktan sonra maliyet düşürme faaliyetlerine girişilmekte iken maliyet yönetim sisteminde maliyetler önlenebilecek unsurlar olarak düşünülmekte ve bu maliyetler daha oluşmadan planlamaları yapılmakta ve önleme çalışmalarına başlanmaktadır.

Maliyet yönetim sistemini bütünleyen yaklaşımlar; Geliştirilmiş Maliyet Takibi, Değer Katmayan Maliyetlerin Ortadan Kaldırılması, Mamul Yaşam Dönemince Maliyetleme, Öğrenme (Deneyim) Eğrisi Maliyetleme, Toplam Kalite Yönetimi ve Kalite Maliyetleri, Tam Zamanında Üretim Ortamında Maliyet Muhasebesi, Faaliyet Tabanlı Maliyetleme, Kaizen ve Hedef Maliyetleme olarak siralanabilir (Karcıoğlu, 2000; Grundy, 1996).

Son yıllarda ise maliyet yönetimi kavramından beklentilerin daha da arttığı stratejik maliyet yönetimi kavramı sıkça kullanılmaya başlanmıştır. Stratejik maliyet yönetimi, karar verme ve analiz yapmada, önceliklerin belirlenmesinde, işletmenin rekabetçi avantajının geliştirilmesinde, kaynakların etkin dağıtılmasına, maliyetleri düşürerek ve değer yaratarak işletmelere yardımcı olur (Ellram ve Stanley, 2008). Stratejik maliyet yönetiminin ilişkide bulunduğu gruplar işletme yöneticileri, finans bölümü, üretim bölümü yöneticileri ve işletme danışmanları ile proje yöneticileridir.

\section{3. İnşaat İşletmeleri ve Maliyet Yönetimi}

İnşaat sektörü, kendisine bağlı 200'den fazla alt sektörün ürettiği mal ve hizmete talep yaratan konumunda olup, bu yaygın etki, sektörün "ekonominin lokomotifi” olma özelliğinin en temel göstergesidir. Yüksek derecede yerli sanayiye dayanması ve dişa bağımlı olmaması, inşaat malzemesi sanayisinde talebin büyük kısmının iç kaynaklarla karşılanması ve böylece yan sanayileri de destekliyor olması, yüksek katma değer oluşturması, taşıdığı yükssek istihdam potansiyeli ve yurtdışında gerçekleştirilen faaliyetlerin döviz kazandırıcı niteliği lokomotif olarak tanımlanmasını destekler niteliktedir (Ekinci, 2006). Çok sayıda sektörle girdi çıktı ilişkisi bulunduğu için gelişmişlik düzeyi ne olursa olsun inşaat sektörü, ülke ekonomileri içinde kilit sektörler grubunda yer alarak, ülke ekonomilerinin kalkınmasında 
önemli rol oynar (Erden, 1997). Uluslararası inşaat sektörü dergisi Engineering News Record'un (ENR), işletmelerin bir önceki y1l gelirlerini dikkate alarak "En Büyük 250" listesini hazırlamaktadır. 2014 yılında 42 Türk inşaat işletmesi bu listede Çin'in 63 inşaat işletmesinin ardından ikinci sıradaki yer almıştır (http://www.enka.com/Pdf/2014_ENR-Top250-International-Contractors-List.pdf).

İnşaat işletmeleri, genelde yoğun rekabet ortamında, çok karmaşık, birçok farklı uzmanlık alanına ait aktiviteleri koordine ederek, süre, kaynak ve maliyet sınırlaması içerisinde farklı türde ve nitelikte yapılara ilişkin yapım faaliyetlerini planlayan, gerçekleştiren ve kontrol eden işletmeler şeklinde tanımlanabilmektedir (Ocakç1, 2007). İngiltere'de yapılan bir araştırmanın sonuçlarına göre, ortalama yeni bir evde 150 farklı meslek kolunu ilgilendiren 23.000 parça bulunmaktadır. Hiçbir ekonomik faaliyetin bu kadar çok doğrudan ya da dolaylı etki doğurma gücü olmadığı dikkate alındığında sektörün lokomotif gücünün, gelişmekte olan ülkeler için vazgeçilemez değeri daha açık olarak ortaya çıkmaktadır (http://intes.org.tr/content/MArt-2014.pdf).

İnşaat işletmeleri, sahip oldukları bu özellikler nedeniyle amaçlarına ulaşabilmek ve en önemlisi faaliyetlerini sürdürebilmek için maliyet yönetimini iyi bir şekilde uygulamak zorundadirlar.

\section{Araştırmanın Amacı}

Üretim işletmelerinde yoğun bir şekilde kullanılmakta olan maliyet yönetimi tekniklerinin inşaat işletmelerinde kullanılma düzeylerinin belirlenmesi, işletmelerin bu tekniklerden beklentilerinin ortaya konulması ve maliyet yönetimini kullanmayan işletmelerin neden kullanmadıklarının belirlenmesidir.

\section{Araştırmanın Önemi}

Değişen piyasa koşullarında işletmelerin faaliyetlerini sürdürebilmeleri için müşteri ihtiyaç ve beklentilerini tam zamanında ve kalitede karşılarken en düşük maliyete ulaşarak hedefledikleri kar'1 elde etmeleri zorunlu hale gelmiştir. $\mathrm{Bu}$ nedenle işletmeler, maliyetlerinin belirlenmesinde ve yönetilmesinde stratejik maliyet yönetiminden yararlanmaya başlamışlardır. $\mathrm{Bu}$ çalışmada inşaat işletmelerinin maliyet yönetimi kapsamında gerçekleştirdikleri faaliyetler ve işletmelerin beklentilerinin neler olduğu belirlenmeye çalışılmıştır.

\section{Araştırmanın Ana Kütlesi, Kapsamı ve Sınırlılıkları}

Araştırmanın ana kütlesi Türkiye İnşaat Sanayicileri İşveren Sendikası (İNTES), Türkiye İnşaat Malzemesi Sanayicileri Derneği (IMSAD) ve Borsa İstanbul (BİST) 100 endeksinde yer alan inşaat işletmeleridir. IMSAD listesinde yer alan inşaat malzemesi işletmeleri, araştırmanın kapsamı dışında bırakılmış, sadece inşaat işletmeleri anket kapsamına alınmıştır. Araştırmanın ana kütlesi bu düzenleme sonrasında 533 işletme olarak belirlenmiştir. İNTES, İMSAD ve BİST 100'deki işletmelerin araştırmanın ana kütlesini oluşturmasında bu işletmelerin diğerlerine göre daha büyük, kurumsallaşmış ve bilgilerine daha kolay ulaşılabilir işletmeler olması en önemli nedendir. 
Araştırmamızda aşağıda maddeler halinde sıralanan konularla ilgili işletmelerden bilgi alınmaya çalışılmıştır.

- İnşaat sektöründe rekabet seviyesi nedir? İşletmelerin rekabet üstünlüğü sağlama yöntemleri ve rekabet stratejileri nelerdir?

- İşletmelerin pazar araştırmasına verdikleri önem düzeyi nedir ve ne zaman pazar araştırması yapmaktadırlar?

- İşletmelerin projelerinin maliyetlerini nasıl belirledikleri, maliyet azaltımı için neler yaptıkları ve işletme bölümlerinin maliyet azaltma faaliyetlerine katılım düzeyleri nedir? nedir?

- İşletmelerin alt yüklenicilerle olan ilişkileri ve alt yüklenicilerle çalışma düzeyleri

Basit tesadüfi örneklem yöntemine göre ana kütleye ilişkin standart sapma ve varyansların bilinmediği durumlarda örneklem büyüklüğü $\% 95$ güven aralığında ve $\% 5$ hata payı ile 107 işletme olarak hesaplanmıştır. Araştırma kapsamında yukarıda belirtilen 533 işletme telefonla aranarak randevu talebinde bulunulmuş, bu işletmelerden 155 işletme hazırlanan anketi cevaplamayı kabul etmiştir. Değerlendirmeye alınan anket sayısı ana kütlenin \% 29'unu oluşturmaktadır. Gerek ulusal gerekse uluslararası literatür taranarak oluşturulan anket formu (Koçsoy, 2008; Bozdemir ve Orhan, 2011; Savaş, 2003; Ax vd., 2008, Chan vd., 2011; Göktürk, 2007; Alp, 2010; Ahmadov, 2006; Coşkun, 2008) işletme sahibi, muhasebe müdürü, finans veya satın alma müdürleri tarafından cevaplanmıştır. Elde edilen veriler tanımlayıcı istatistik yöntemleri kullanılarak (frekans, yüzde) tablolar halinde sunulmuştur.

\section{Araştırmanın Bulguları}

İnşaat işletmelerinin faaliyet gösterdikleri piyasadaki rekabet koşulları, fiyatlama kararları ve tedarikçileri ile olan ilişkileri, bu işletmelerin maliyet yönetimi anlamında ne gibi uygulamalar yaptıklarını ortaya koymak açısından oldukça önemlidir.

Anketi cevaplayan işletmelerin sektördeki faaliyet sürelerinin gösterildiği Tablo 1'de anketi cevaplayan işletmelerin \%36,8'inin 20 yıldan daha fazla inşaat sektöründe faaliyette bulunduğu görülmektedir.

Tablo 1. Anketi Cevaplayan İşletmelerin Sektördeki Faaliyet Süreleri

\begin{tabular}{l|l|l}
\hline & Frekans & Yüzde \\
\hline 3ylldan az & 6 & $\mathbf{3 , 9}$ \\
\hline 3-5 yıl & 10 & $\mathbf{6 , 5}$ \\
\hline $\mathbf{5 - 1 0}$ yıl & 37 & $\mathbf{2 3 , 9}$ \\
\hline $\mathbf{1 0 - 2 0}$ yıl & 45 & $\mathbf{2 9 , 0}$ \\
\hline $\mathbf{2 0}$ yıldan fazla & 57 & $\mathbf{3 6 , 8}$ \\
\hline Toplam & $\mathbf{1 5 5}$ & $\mathbf{1 0 0 , 0}$ \\
\hline
\end{tabular}

İşletmelerin büyük bir bölümünün sektörde 20 yıldan daha fazla varlıklarını sürdürmüş olmaları onların rekabet ve ekonomik krizler açısından doğru kararları vermiş olduklarının bir göstergesi olarak değerlendirilebilir. 
İşletmelerin yıllık ciro rakamlarının gösterildiği Tablo 2'ye bakıldığında, 7 işletmenin $(\% 4,5)$ 1.000.000 TL'den az, 16 işletmenin (\%10,3) 1.000.000-10.000.000 TL arasında, 33 işletmenin $(\% 21,3)$ 10.000.000-20.000.000 TL arasında, 65 işletmenin $(\% 41,9)$ 20.000.00050.000.000 TL arasında, 34 işletme $(\% 21,9) 50.000 .000$ TL üzerinde yıllık ciroya sahip olduğu belirlenmiştir. Bu rakamlara göre işletmelerin yıllık cirolarına bakıldığında önemli büyüklüklere sahip oldukları görülmektedir.

Tablo 2. İşletmelerin Ortalama Yıllık Cirosu

\begin{tabular}{|c|c|c|}
\hline & Frekans & Yüzde \\
\hline 1.000.000 TL'den az & 7 & 4,5 \\
\hline $1.000 .000-10.000 .000 \mathrm{TL}$ & 16 & 10,3 \\
\hline 10.000.000 -20.000.000 TL & 33 & 21,3 \\
\hline 20.000.000-50.000.000 TL & 65 & 41,9 \\
\hline 50.000.000 TL üzeri & 34 & 21,9 \\
\hline Toplam & 155 & 100,0 \\
\hline
\end{tabular}

Anketi cevaplayan işletmeler faaliyet gösterdikleri pazarlar açısından incelendiğinde (Tablo 3), 118 işletme sadece ulusal pazarda, 2 işletme uluslararası pazarda, 35 işletme ise hem ulusal hem de uluslararası pazarlarda faaliyet göstermektedir. 70'li yıllardan itibaren yurtdışında projeler üstlenmeye başlayan işletmeler her geçen yıl üstlendikleri proje sayısını ve faaliyet gösterdikleri ülke sayısını artırmışlardır. Araştırmamıza katılan işletmelerin halen $\% 76,1$ 'i sadece ulusal sınırlarda faaliyet gösterse de \%22,6'sının yurtdışı projelerde de yer almasi gelecek vaat etmektedir.

Tablo 3. İşletmelerin Faaliyet Gösterdiği Pazar

\begin{tabular}{l|l|l}
\hline & Frekans & Yüzde \\
\hline Ulusal & 118 & $\mathbf{7 6 , 1}$ \\
\hline Uluslararası & 2 & $\mathbf{1 , 3}$ \\
\hline Hem ulusal hem de uluslararası & 35 & $\mathbf{2 2 , 6}$ \\
\hline Toplam & $\mathbf{1 5 5}$ & $\mathbf{1 0 0 , 0}$ \\
\hline
\end{tabular}

Anketi cevaplayan kişilerin işletmedeki pozisyonlarının gösterildiği Tablo 4'te ise, Muhasebe yöneticilerinin 73 kişi ile ilk sırada yer aldığı, 7 kişinin pazarlama/satış bölümünde, 45 kişinin işletme yetkilisi, 14 kişinin finans bölümünde, 8 kişinin proje danışmanı, 6 kişinin mimar, 2 kişinin de ihale koordinatörü olduğu görülmektedir. Çalışma esnasında ankete cevap veren önemli sayıda işletme yetkilisinin (işletme sahibi, genel müdür, bölüm müdürü) olduğu, işletme yetkililerinin maliyet yönetimi ile yakından ilgilendikleri ve çalışanlarına gerekli desteği verdikleri görüşü sonuçlarla doğrulanmıştır. 
Tablo 4. Ankete Cevap Veren Kişilerin İşletmedeki Pozisyonları

\begin{tabular}{l|l|l}
\hline & Frekans & Yüzde \\
\hline Muhasebe & 73 & $\mathbf{4 7 , 1 0}$ \\
\hline Pazarlama/Satış & 7 & $\mathbf{4 , 5 2}$ \\
\hline Finans & 14 & $\mathbf{9 , 0 3}$ \\
\hline İşletme yetkilisi & 45 & $\mathbf{2 9 , 0 3}$ \\
\hline Proje danışmanı & 8 & $\mathbf{5 , 1 6}$ \\
\hline Mimar & 6 & $\mathbf{3 , 8 7}$ \\
\hline İhale koordinatörü & 2 & $\mathbf{1 , 2 9}$ \\
\hline Toplam & $\mathbf{1 5 5}$ & $\mathbf{1 0 0 , 0}$ \\
\hline
\end{tabular}

Tablo 5'te Türk inşaat işletmelerinin faaliyette bulundukları piyasanın rekabet seviyesini tanımlamaları istenmiş ve sonuç olarak; işletmelerin \%23,9'unun "orta derecede rekabetin" bulunduğunu, \%30,3'ünün "rekabet çok" olarak tanımladığı ve işletmelerin \%44,5'inin ise piyasada "aşırı derecede rekabet" olduğunu belirttikleri görülmektedir. Tüm sektörlerde olduğu gibi inşaat sektöründe de rekabetin fazla olduğu, bu rekabetin özellikle ülkemizde de kullanılmaya başlanan mortgage sistemi ile doruk noktasına ulaştığı söylenebilir.

Tablo 5. İşletmelerce Faaliyet Gösterdikleri Piyasanın Rekabet Seviyesinin Tanımlanması

\begin{tabular}{l|l|l}
\hline & Frekans & Yüzde \\
\hline Rekabet yok & 1 & $\mathbf{6}$ \\
\hline Rekabet az & 1 & $\mathbf{6}$ \\
\hline Orta derecede rekabet & 37 & $\mathbf{2 3 , 9}$ \\
\hline Rekabet çok & 47 & $\mathbf{3 0 , 3}$ \\
\hline Aşırı derecede rekabet var & 69 & $\mathbf{4 4 , 5}$ \\
\hline Toplam & $\mathbf{1 5 5}$ & $\mathbf{1 0 0 , 0}$ \\
\hline
\end{tabular}

İşletmeler gerek pazara girişte gerekse faaliyetlerine devam ederken hedeflerine ulaşabilmek için belirledikleri rekabet stratejileri doğrultusunda stratejiler geliștirirler ve uygularlar. Porter'ın geliştirdiği rekabet stratejilerden ilki daha düşük maliyetle üretim yapıp, daha düşük fiyatla satmak olan maliyet liderliğidir. Diğer rekabet stratejisi belirli bir müşteri grubunun seçilerek o grubun istediği kalite ve özellikte ürünleri sunmayı amaçlayan farklılaşma stratejisidir. Son strateji ise, işletmelerin belirli bir üretim alanında değişim mühendisliği veya farklılaşma tekniklerini kullanarak rekabet etmesidir (Dess, 1984).

İnşaat işletmeleri için bu stratejilerin önem derecesini belirleyebilmek amaciyla yönelttiğimiz bu soruya verilen cevaplar doğrultusunda hazırlanan Tablo 6, işletmelerin \% 94,2'si için öncelikle belirli bir müşteri grubunu hedefleyerek, kaliteli ve müşteriyi tatmin eden binalar sunmak yani farklılaşma stratejisinin önemli olduğu, \% 94,1'i için ise yüksek kaliteli, standart olmayan yenilikçi binalar inşa ederek rekabet etmenin yani odaklanma 
stratejisinin, \% 76,2'si için ise daha düşük maliyetle bina üretip daha düşük fiyatla satmak olan maliyet liderliği stratejisini tercih ettikleri belirlenmiştir ${ }^{4}$.

Tablo 6. İşletmelerin Uyguladıkları Rekabet Stratejileri

\begin{tabular}{|c|c|c|c|c|c|c|c|}
\hline & & 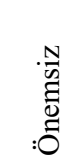 & 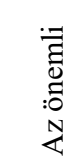 & $\begin{array}{l}\overline{\bar{\Xi}} \\
: 0\end{array}$ & 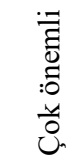 & $\begin{array}{l}: \bar{\Xi} \\
\text { : } \\
: 0 \\
\text { 武 }\end{array}$ & $\frac{\text { है }}{\frac{\pi}{2}}$ \\
\hline \multirow{2}{*}{$\begin{array}{l}\text { Daha düşük maliyetle } \\
\text { bina üretip daha düşük } \\
\text { fiyatla satmak }\end{array}$} & Frekans & 6 & 31 & 48 & 66 & 4 & 155 \\
\hline & $\%$ & 3,8 & 20,0 & 31,0 & 42,6 & 2,6 & 100 \\
\hline \multirow{2}{*}{\begin{tabular}{lcc} 
Belirli & bir & müşteri \\
grubunu & \multicolumn{2}{c}{ hedefleyerek, } \\
kaliteli & ve & müşsteriyi \\
tatmin & edici & binalar \\
sunmak & & \\
\end{tabular}} & Frekans & 3 & 6 & 53 & 88 & 5 & 155 \\
\hline & $\%$ & 1,9 & 3,9 & 34,2 & 56,8 & 3,2 & 100 \\
\hline \multirow{2}{*}{$\begin{array}{lr}\text { Yüksek kaliteli, } & \text { standart } \\
\text { olmayan } & \text { yenilikçi } \\
\text { binalar inşa } & \text { ederek } \\
\text { rekabet etmek } & \end{array}$} & Frekans & 5 & 4 & 54 & 85 & 7 & 155 \\
\hline & $\%$ & 3,2 & 2,6 & 34,8 & 54,8 & 4,5 & 100 \\
\hline
\end{tabular}

Tablo 7'ye göre, işletmelerin \%58,1'inin yeni bir proje üretmeden önce yeterli düzeyde pazar araştırması yaptıkları, 54 işletmenin \%34,8'inin kısmen pazar araştırması yaptıkları, işletmelerin \% 7,1'inin ise hiçbir şekilde pazar araştırması yapmadıkları belirlenmiştir. İnşaat sektöründe özellikle ülkelerin gelişme seviyeleri ile bağlantılı olarak talep edilen projelerin de türü ve özellikleri değişmektedir. Özellikle konut projelerinde son yıllarda yaşanan gelişmelerle birlikte müşterilerin ihtiyaç ve isteklerinin belirlenmesi ve bunlar için ödemeyi düşündükleri bütçenin belirlenmesi ilk ve en önemli adım haline gelmiştir. Bu sayede geliştirilen projeler müşterilerce kabul görmekte, işletmeler ise satış kısmında sorun yaşamamaktadırlar.

Tablo 7. Yeni Bir Proje Üretmeden Önce İşletmelerin Pazar Araştırması Yapma Düzeyleri

\begin{tabular}{l|l|l}
\hline & Frekans & Yüzde \\
\hline Yeterli düzeyde yapıyoruz & 90 & $\mathbf{5 8 , 1}$ \\
\hline Kısmen yapıyoruz & 54 & $\mathbf{3 4 , 8}$ \\
\hline Hiç yapmiyoruz & 11 & $\mathbf{7 , 1}$ \\
Toplam & $\mathbf{1 5 5}$ & $\mathbf{1 0 0 , 0}$ \\
\hline
\end{tabular}

İşletmelerin yeni bir proje ile ilgili maliyet düşürme çalışmalarını hangi aşamada gerçekleştirdiklerine ilişkin bilgilere ait Tablo 8'e baktığımızda, işletmelerin \%27,7'sinin proje fikri oluştuktan hemen sonra, $\% 40,0$ 'ının proje tasarımı ve geliştirilmesi aşamasında,

\footnotetext{
${ }^{4}$ Yüzdeler önemli, çok önemli ve en önemli seçeneklerini ifade etmektedir.
} 
$\% 26,5$ 'inin proje esnasında, \%5,2'sinin proje tamamlandıktan sonra \%0,6'sının ise hiçbir aşamada maliyet tahmini ve düşürme çalışması yapmadıkları belirlenmiştir.

Tablo 8. İşletmelerin Yeni Bir Proje ile İlgili Maliyet Düşürme Çalışmalarını Hangi Aşamada Gerçekleştirdikleri

\begin{tabular}{l|l|l}
\hline \multicolumn{1}{c|}{ Gerçekleştirdikleri } & Frekans & Yüzde \\
\hline Proje fikri oluştuktan hemen sonra & 43 & $\mathbf{2 7 , 7}$ \\
\hline Proje tasarımı ve geliştirilmesi aşamasında & 62 & $\mathbf{4 0 , 0}$ \\
\hline $\begin{array}{l}\text { Proje esnasında } \\
\text { Proje tamamlandıktan sonra }\end{array}$ & 41 & $\mathbf{2 6 , 5}$ \\
\hline $\begin{array}{l}\text { Hiçbir aşamada maliyet tahmini ve düşürme çalışması } \\
\text { yapılmamaktadır. }\end{array}$ & 1 & $\mathbf{5 , 2}$ \\
\hline \begin{tabular}{l} 
Toplam \\
\hline
\end{tabular} & $\mathbf{1 5 5}$ & $\mathbf{, 6}$ \\
\hline
\end{tabular}

İşletmeler için maliyet düşürme çabalarının en verimli şekilde yapılabileceği dönem olarak proje tasarımı aşaması ve hatta proje fikrinin oluşması aşamasının olduğu çeşitli çalışmalarda belirtilmiş bu nedenle de işletmelerin bu aşamalarda maliyet düşürme çabalarına odaklanmaları önerilmiştir. Sonuçlara göre işletmeler projenin fikir aşamasında ve tasarım aşamasında maliyet düşürme çabalarına odaklanarak bu avantajdan yararlanmaktadırlar. Bunun yanı sıra işletmelerin $\% 26,5$ 'inin proje esnasında maliyet düşürme faaliyetlerini gerçekleştirdiğini belirterek aslında maliyetlerinde istenilen düşüşü gerçekleştiremeyeceklerinin sinyalini vermektedirler.

İnşaat işletmelerinde alt yüklenicilerle çalışma oldukça sık rastlanan bir durumdur. İşletmelerin "Projelerinizde alt yüklenicilerle çalışma yüzdeniz nedir?" sorusuna verdikleri cevaplara baktığımızda 26 İşletmenin \% 0-20 arasında, 23 işletmenin \% 21-40 arasında, 33 işletmenin \%41-60 arasında, 38 işletmenin \%61-80 arasında, 35 işletmenin ise \%81-100 arasındaki projesinde alt yükleniciler ile çalıştıklarını belirtmişlerdir. Bu soruya ait veriler Tablo 9'da yer almaktadır. İşletmeler alt yüklenicilerle çalışarak daha fazla projeyi aynı zaman diliminde gerçekleştirirken, alt yüklenicilerin işgücü, makine, alet-teçhizat, uzmanlık ve deneyimlerinden de yararlanmaktadırlar.

Tablo 9. İşletmelerin Projelerde Alt Yüklenicilerle Çalışma Yüzdeleri

\begin{tabular}{l|l|l}
\hline & Frekans & Yüzde \\
\hline$\% 0-20$ & 26 & $\mathbf{1 6 , 8}$ \\
\hline$\% 21-40$ & 23 & $\mathbf{1 4 , 8}$ \\
\hline$\% 41-60$ & 33 & $\mathbf{2 1 , 3}$ \\
\hline$\% 61-80$ & 38 & $\mathbf{2 4 , 5}$ \\
\hline$\% 81-100$ & 35 & $\mathbf{2 2 , 6}$ \\
\hline Toplam & 155 & $\mathbf{1 0 0 , 0}$ \\
\hline
\end{tabular}


İşletmelerin maliyet azaltma faaliyetlerini yapma nedenleri ve bunların işletmeler için önem düzeylerinin belirlenmesine yönelik soru sonucunda hazırlanan Tablo 10'a göre, işletmelerin sırasıyla düşük maliyet seviyesinde daha yüksek kar elde etmek $(\% 92,9)$, hedef kâra ve hedef maliyete ulaşabilmek $(\% 98,1)$, düşük maliyet sayesinde düşük satış fiyatı ile pazara girebilmek $(\% 79,3)$, rekabet gücünü korumak ve pazar payını artırmak $(\% 97,4)$ amaçlarına yüzdelerle belirtilen önem dereceleri ile sahip oldukları belirlenmiştir ${ }^{5}$.

Tablo 10. İşletmelerin Maliyet Azaltma Faaliyetlerinin Sebepleri ve Önem Düzeyleri

\begin{tabular}{|c|c|c|c|c|c|c|c|}
\hline & & 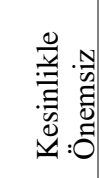 & 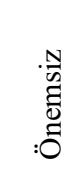 & 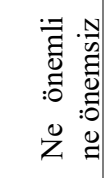 & :0 & 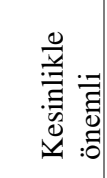 & \\
\hline \multirow{2}{*}{$\begin{array}{l}\text { Düşük maliyet sayesinde düşük satış } \\
\text { fiyatı ile pazara girebilmek }\end{array}$} & Frekans & 4 & 6 & 22 & 114 & 9 & 155 \\
\hline & $\%$ & 2,6 & 3,9 & 14,2 & 73,5 & 5,8 & 100 \\
\hline \multirow{2}{*}{$\begin{array}{l}\text { Düşük maliyet sayesinde daha yüksek } \\
\text { kar elde edebilmek }\end{array}$} & Frekans & 2 & - & 9 & 119 & 25 & 155 \\
\hline & $\%$ & 1,3 & - & 5,8 & 76,8 & 16,1 & 100 \\
\hline \multirow{2}{*}{$\begin{array}{l}\text { Hedef kâra ve hedef maliyete } \\
\text { ulaşabilmek }\end{array}$} & Frekans & - & - & 3 & 117 & 35 & 155 \\
\hline & $\%$ & - & - & 1,9 & 75,5 & 22,6 & 100 \\
\hline \multirow[t]{2}{*}{ Rekabet gücünü korumak } & Frekans & - & - & 1 & 111 & 43 & 155 \\
\hline & $\%$ & - & - & 6 & 71,6 & 27,7 & 100 \\
\hline \multirow[t]{2}{*}{ Pazar payını artırmak } & Frekans & - & - & 4 & 105 & 46 & 155 \\
\hline & $\%$ & - & - & 2,6 & 67,7 & 29,7 & 100 \\
\hline
\end{tabular}

Tablo 11. İşletmelerin Ürün Maliyetlerini Azaltmak İçin Uyguladıkları Faaliyetler

\begin{tabular}{|c|c|c|c|c|c|c|c|}
\hline & & 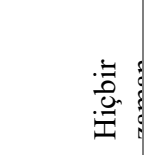 & 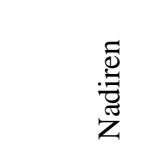 & 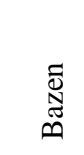 & 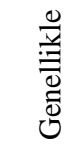 & 矛 & $\frac{\Xi}{\frac{\pi}{2}}$ \\
\hline \multirow{2}{*}{$\begin{array}{l}\text { Kaliteli fakat ucuz hammadde ve } \\
\text { malzeme sağlamak için az sayıda } \\
\text { tedarikçi ile uzun süreli çalışmak }\end{array}$} & Frekans & 1 & 2 & 44 & 89 & 19 & 155 \\
\hline & $\%$ & 0,6 & 1,3 & 28,4 & 57,4 & 12,3 & 100 \\
\hline \multirow{2}{*}{$\begin{array}{l}\text { Farklı kalitede ucuz hammadde } \\
\text { malzeme sağlamak }\end{array}$} & Frekans & 9 & 22 & 55 & 63 & 6 & 155 \\
\hline & $\%$ & 5,8 & 14,2 & 35,5 & 40,6 & 3,9 & 100 \\
\hline \multirow[t]{2}{*}{ İnşaat süreçlerini gözden geçirmek } & Frekans & 1 & 5 & 52 & 74 & 23 & 155 \\
\hline & $\%$ & 0,6 & 3,2 & 33,5 & 47,7 & 14,8 & 100 \\
\hline \multirow{2}{*}{$\begin{array}{l}\text { İnşaat maliyetini artıran özellikleri } \\
\text { çıkartarak sadeliğe gitmek }\end{array}$} & Frekans & 4 & 11 & 71 & 65 & 4 & 155 \\
\hline & $\%$ & 2,6 & 7,1 & 45,8 & 41,9 & 2,6 & 100 \\
\hline \multirow{2}{*}{$\begin{array}{l}\text { İşletme genelindeki tüm faaliyetlerde } \\
\text { verimliliği artırmak }\end{array}$} & Frekans & 2 & 13 & 45 & 69 & 26 & 155 \\
\hline & $\%$ & 1,3 & 8,4 & 29,0 & 44,5 & 16,8 & 100 \\
\hline
\end{tabular}

\footnotetext{
5 Yüzdeler önemli ve kesinlikle önemli seçeneklerini ifade etmektedir.
} 
İşletmelerin ürün maliyetlerini azaltmak için gerçekleştirdikleri faaliyetlerin sıklık dereceleri Tablo 11'de verilmiştir. Buna göre işletmelerin, az sayıda tedarikçi ile uzun süreli çalışarak, kaliteli fakat ucuz hammadde ve malzeme sağlamayı amaçladıkları, inşaat süreçlerini gözden geçirdikleri, işletme genelindeki tüm faaliyetlerde verimliliği artırmaya çalıştıkları, inşaat maliyetlerini artıran özellikleri çıkartarak sadeliğe gittikleri ve farklı kalitede ucuz hammadde malzeme sağlamayı amaçladıkları belirtilmiştir.

Tablo 12. İşletmelerde Yer Alan Bölümlerin Ürün Maliyetinin Belirlenmesi ve Azaltımı Çalışmalarına Katılma Dereceleri

\begin{tabular}{|c|c|c|c|c|c|c|c|}
\hline & & 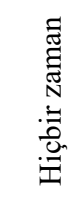 & 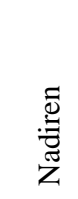 & 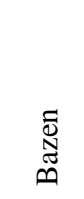 & 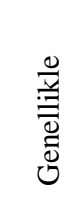 & 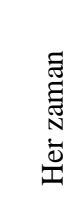 & $\frac{\Xi}{\tilde{0}}$ \\
\hline \multirow[t]{2}{*}{ Mali işler } & Frekans & 2 & 2 & 8 & 122 & 21 & 155 \\
\hline & $\%$ & 1,3 & 1,3 & 5,2 & 78,7 & 13,5 & 100 \\
\hline \multirow[t]{2}{*}{ Satış/pazarlama } & Frekans & 3 & 4 & 28 & 105 & 15 & 155 \\
\hline & $\%$ & 1,9 & 2,6 & 18,1 & 67,7 & 9,7 & 100 \\
\hline \multirow[t]{2}{*}{ Planlama } & Frekans & 1 & 4 & 29 & 89 & 32 & 155 \\
\hline & $\%$ & 0,6 & 2,6 & 18,7 & 57,4 & 20,6 & 100 \\
\hline \multirow[t]{2}{*}{ Satın alma } & Frekans & - & 2 & 20 & 109 & 24 & 155 \\
\hline & $\%$ & - & 1,3 & 12,9 & 70,3 & 15,5 & 100 \\
\hline \multirow[t]{2}{*}{ Mühendislik } & Frekans & 5 & 19 & 49 & 52 & 30 & 155 \\
\hline & $\%$ & 3,2 & 12,3 & 31,6 & 33,5 & 19,4 & 100 \\
\hline \multirow[t]{2}{*}{ Makine/donanım } & Frekans & 16 & 38 & 45 & 45 & 11 & 155 \\
\hline & $\%$ & 10,3 & 24,5 & 29,0 & 29,0 & 7,1 & 100 \\
\hline \multirow[t]{2}{*}{ Lojistik } & Frekans & 42 & 39 & 30 & 34 & 10 & 155 \\
\hline & $\%$ & 27,1 & 25,2 & 19,4 & 21,9 & 6,5 & 100 \\
\hline \multirow[t]{2}{*}{ Tedarikçiler } & Frekans & 6 & 26 & 55 & 55 & 13 & 155 \\
\hline & $\%$ & 3,9 & 16,8 & 35,5 & 35,5 & 8,4 & 100 \\
\hline \multirow[t]{2}{*}{ İnsan kaynakları } & Frekans & 46 & 44 & 21 & 31 & 13 & 155 \\
\hline & $\%$ & 29,7 & 28,4 & 13,5 & 20,0 & 8,4 & 100 \\
\hline \multirow[t]{2}{*}{ Mimarlık } & Frekans & 4 & 16 & 70 & 41 & 24 & 155 \\
\hline & $\%$ & 2,6 & 10,3 & 45,2 & 26,5 & 15,5 & 100 \\
\hline
\end{tabular}

Ürün maliyetlerini belirleme ve azaltma çabalarına katılma derecesi açısından işletme bölümleri incelendiğinde (Tablo 12) genellikle cevabına ait bilgilere dayanarak sirasıyla, mali işler, satın alma, satış/pazarlama, planlama, tedarikçiler, mühendislik, makine donanım, mimarlık, lojistik ve insan kaynaklarının etkili oldukları belirlenmiştir. 
İşletmelerin alt yüklenici ve tedarikçileri ile olan ilişkilerini ortaya koyabilmek ve anlayabilmek için verilen ifadelere katılma derecelerinin verildiği Tablo 13'te, işletmelerin $(\% 96,1)$ inşaat ile ilgili tüm konularda alt yüklenici ve tedarikçilerle sürekli koordinasyon halinde olduklarını, $(\% 85,8)$ maliyet hedeflerine ulaşmak için alt yüklenicileri/tedarikçileri kontrol altında tutar ve onlara maliyet hedefleri belirlediklerini, $\left(\begin{array}{l}\% \\ 83,2\end{array}\right)$ alt yüklenicilerin/tedarikçilerin kendilerine çok bağımlı olduğunu, (\% 80,6) alt yüklenici yaptığ1 faaliyetler nedeniyle maliyetleri düşürürse elde edilen tasarrufun onların olacağını bildiklerini, $(\% 75,5)$ alt yüklenicilere eğitim ve destek verdiklerini belirtmişlerdir ${ }^{6}$.

Tablo 13. İşletmelerin Alt Yüklenicilerle ve Tedarikçilerle Olan İlişkilerine İlişkin İfadelere Katılma Dereceleri

\begin{tabular}{|c|c|c|c|c|c|c|c|}
\hline & & 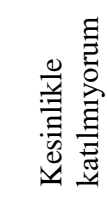 & 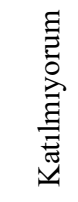 & 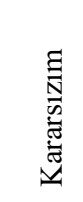 & 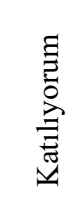 & 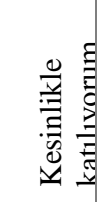 & $\frac{\Xi}{\frac{\pi}{2}}$ \\
\hline \multirow{2}{*}{$\begin{array}{l}\text { İnşaat ile ilgili tüm } \\
\text { yüklenicilerle/tedarikçilerle } \\
\text { koordinasyon halindeyiz }\end{array}$} & Frekans & 2 & 3 & 1 & 131 & 18 & 155 \\
\hline & $\%$ & 1,3 & 1,9 & 6 & 84,5 & 11,6 & 100 \\
\hline \multirow{2}{*}{$\begin{array}{l}\text { Maliyet hedeflerine ulaşmak için alt } \\
\text { yüklenicileri/tedarikçileri kontrol altında } \\
\text { tutar ve onlara maliyet hedefleri belirleriz }\end{array}$} & Frekans & 2 & 15 & 5 & 124 & 9 & 155 \\
\hline & $\%$ & 1,3 & 9,7 & 3,2 & 80,0 & 5,8 & 100 \\
\hline \multirow{2}{*}{$\begin{array}{l}\text { Alt yüklenicilerimiz/tedarikçilerimiz iş için } \\
\text { bize çok bağımlıdır }\end{array}$} & Frekans & 2 & 15 & 9 & 120 & 9 & 155 \\
\hline & $\%$ & 1,3 & 9,7 & 5,8 & 77,4 & 5,8 & 100 \\
\hline \multirow[t]{2}{*}{ Alt yüklenicilerimize eğitim ve destek veririz } & Frekans & 3 & 24 & 11 & 110 & 7 & 155 \\
\hline & $\%$ & 1,9 & 15,5 & 7,1 & 71,0 & 4,5 & 100 \\
\hline \multirow{2}{*}{$\begin{array}{l}\text { Alt yüklenici yaptığı faaliyetler nedeniyle } \\
\text { maliyetleri düşürürse, elde edilen tasarrufun } \\
\text { onun olacağını bilir. }\end{array}$} & Frekans & 3 & 15 & 12 & 114 & 11 & 155 \\
\hline & $\%$ & 1,9 & 9,7 & 7,7 & 73,5 & 7,1 & 100 \\
\hline
\end{tabular}

İşletmelerin yeni bir projenin tasarımı aşamasında yaptıkları çalışmalarla öngörülen maliyet hedeflerinin aşıldığını fark etmeleri durumunda başvurdukları eylemlerin sıklık dereceleri Tablo 14'de sırasıyla; projenin hedeflenen satış fiyatı artırılır $(\% 48,4)$, tedarikçiler ve altyüklenicilerle uzun dönemli anlaşmalar yapılır (\% 38,0), projeden beklenen kar marjı azalt1lır $(\% 28,4)$, projenin özellikleri azalt1lır $(\% 24,5)$, projede kullanılacak girdilerde değişiklik yapılır $(\% 24,5)$, projenin maliyet hedefleri artırılır $(\% 22,5)$, projenin dizaynı değiştirilir (\% 21,9) ve projeden vazgeçilir $(\% 19,4)$ 'tür ${ }^{7}$.

İşletmelere yeni bir yönetim tekniğini kullanmalarına nelerin neden olabileceğini belirlemek amaciyla hazırlanan Tablo 15 'te işletmelerin; $(\% 98,6)$ teknolojik gelişmeler, (\% 100)

\footnotetext{
${ }^{6}$ Yüzdeler katılıyorum ve kesinlikle katılıyorum seçeneklerini ifade etmektedir.

${ }^{7}$ Yüzdeler genellikle ve her zaman seçeneklerini ifade etmektedir.
} 
maliyet odakl1lı̆̆a verilen önem, (\% 98) rekabetin yoğunluğu, $(\% 92,3)$ çevresel değişimler ve $(\% 94,8)$ rakiplerin sayısı seçeneklerini seçtikleri görülmüştür ${ }^{8}$.

Tablo 14. Yeni Bir Projenin Tasarımı Aşamasında Öngörülen Maliyetlerin Aşılması Durumunda İşletmelerin Başvurduğu Eylemlerin Sıklık Dereceleri

\begin{tabular}{|c|c|c|c|c|c|c|c|}
\hline \multicolumn{8}{|c|}{ Işletmelerin Başvurdugu Eylemlerin Sıklık Dereceleri } \\
\hline & & 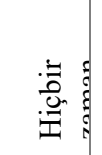 & 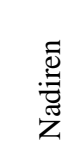 & 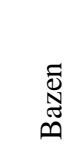 & 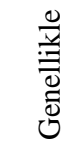 & $\ddot{\overline{0}}$ & 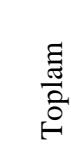 \\
\hline \multirow[t]{2}{*}{ Projenin hedeflenen satış fiyatı artırılır } & Frekans & 6 & 7 & 67 & 73 & 2 & 155 \\
\hline & $\%$ & 3,9 & 4,5 & 43,2 & 47,1 & 1,3 & 100 \\
\hline \multirow[t]{2}{*}{ Projeden beklenen kar marjı azaltılır } & Frekans & 8 & 33 & 7 & 42 & 2 & 155 \\
\hline & $\%$ & 5,2 & 21,3 & 45,2 & 27,1 & 1,3 & 100 \\
\hline \multirow[t]{2}{*}{ Projenin özellikleri azaltılır } & Frekans & 13 & 26 & 78 & 35 & 3 & 155 \\
\hline & $\%$ & 8,4 & 16,8 & 50,3 & 22,6 & 1,9 & 100 \\
\hline \multirow[t]{2}{*}{ Projenin dizaynı değiştirilir } & Frekans & 9 & 43 & 69 & 32 & 2 & 155 \\
\hline & $\%$ & 5,8 & 27,7 & 44,5 & 20,6 & 1,3 & 100 \\
\hline \multirow[t]{2}{*}{ Projede kullanılacak girdilerde değişiklik yapılır } & Frekans & 14 & 21 & 82 & 35 & 3 & 155 \\
\hline & $\%$ & 9,0 & 13,5 & 52,9 & 22,6 & 1,9 & 100 \\
\hline \multirow[t]{2}{*}{ Projenin maliyet hedefleri artırılır } & Frekans & 10 & 24 & 86 & 32 & 3 & 155 \\
\hline & $\%$ & 6,5 & 15,5 & 55,5 & 20,6 & 1,9 & 100 \\
\hline \multirow[t]{2}{*}{ Projeden vazgeçilir } & Frekans & 27 & 76 & 22 & 30 & - & 155 \\
\hline & $\%$ & 17,4 & 49,0 & 14,2 & 19,4 & - & 100 \\
\hline \multirow{2}{*}{$\begin{array}{l}\text { Tedarikçiler ve altyüklenicilerle uzun dönemli } \\
\text { anlaşmalar yapılır }\end{array}$} & Frekans & 4 & 23 & 69 & 56 & 3 & 155 \\
\hline & $\%$ & 2,6 & 14,8 & 44,5 & 36,1 & 1,9 & 100 \\
\hline
\end{tabular}

Tablo 15. İşletmeleri Yeni Bir Maliyet Yönetim Tekniğini Kullanmaya Yönelten Nedenlerin Önem

\begin{tabular}{|c|c|c|c|c|c|c|c|}
\hline & Derec & & & & & & \\
\hline & & 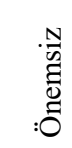 & $\begin{array}{l}: \bar{\nabla} \\
\bar{\Xi} \\
: \overline{0} \\
\mathbb{N}\end{array}$ & $\begin{array}{l}\overline{\bar{E}} \\
: \overline{0}\end{array}$ & 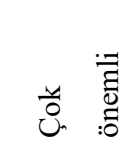 & 牙 & 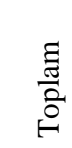 \\
\hline \multirow[t]{2}{*}{ Rakiplerin sayısı } & Frekans & 2 & 6 & 51 & 87 & 9 & 155 \\
\hline & $\%$ & 1,3 & 3,9 & 32,9 & 56,1 & 5,8 & 100 \\
\hline \multirow[t]{2}{*}{ Maliyet odaklılığa verdiğimiz önem } & Frekans & - & - & 48 & 95 & 12 & 155 \\
\hline & $\%$ & - & - & 31,0 & 61,3 & 7,7 & 100 \\
\hline \multirow[t]{2}{*}{ Rekabetin yoğunluğu } & Frekans & - & 3 & 45 & 91 & 16 & 155 \\
\hline & $\%$ & - & 1,9 & 29,0 & 58,7 & 10,3 & 100 \\
\hline
\end{tabular}

\footnotetext{
${ }^{8}$ Yüzdeler önemli, çok önemli ve en önemli seçeneklerini ifade etmektedir.
} 


\begin{tabular}{l|l|l|l|l|l|l|l}
\hline \multirow{2}{*}{ Çevresel değişimler } & Frekans & 1 & 11 & 41 & 94 & 8 & $\mathbf{1 5 5}$ \\
\cline { 2 - 9 } & $\%$ &, 6 & 7,1 & 26,5 & 60,6 & 5,2 & $\mathbf{1 0 0}$ \\
\hline \multirow{2}{*}{ Teknolojik gelişmeler } & Frekans & 1 & 1 & 45 & 96 & 12 & $\mathbf{1 5 5}$ \\
\cline { 2 - 9 } & $\%$ & $\mathbf{, 6}$ & $\mathbf{, 6}$ & $\mathbf{2 9 , 0}$ & $\mathbf{6 1 , 9}$ & $\mathbf{7 , 7}$ & $\mathbf{1 0 0}$ \\
\hline
\end{tabular}

\section{Sonuç}

Bağlantılı olduğu sektörlerle birlikte önemli bir ekonomik büyüklüğe sahip olan inşaat sektörü son y1llarda yaşanan mortgage krizi ve siyasal krizler nedeniyle işletmelerin varlıklarını sürdürmede zorlandıkları bir noktaya gelmiştir. Bu nedenle işletmeler maliyet yönetimi konusuna odaklanmış ve değer zinciri üyelerini de bu sürece dahil etmeye başlamışlardır. Çalışmamızda inşaat işletmelerinin maliyet yönetimi konusunda yaşadıkları sorunları, maliyet yönetimi hakkındaki bilgileri ve maliyet yönetimini uygulama düzeylerine ilişkin tanımlayıcı bilgiler elde edilmiştir. Bu sayede literatürde inşaat sektöründe maliyet yönetimi konusundaki boşluğun doldurulduğu düşünülmektedir. Çalışmamızın sonuçlarına göre;

- İşletmeler sektördeki rekabet düzeyinin oldukça şiddetli olduğunu belirtirken, rakiplerine karşı ağıllıklı olarak yüksek kaliteli, standart olmayan yenilikçi binalar inşa ederek rekabet etmeyi, ikinci olarak ise belirli bir müşteri grubunu hedefleyerek, kaliteli ve müşteriyi tatmin edici binalar sunmayı tercih ettikleri belirlenmiştir. Bu noktada rekabet stratejisi olarak işletmelerin düşük maliyetle bina üretip daha düşük fiyatla satmak olan maliyet liderliğini tercih etmedikleri dikkat çekmektedir.

- İşletmeler için rekabet üstünlügü sağlamada maliyet, yapım işleri, hız, hizmet ve kalite için önem derecelerine bakıldığında, bu unsurların tamamı için önem derecelerinin birbirine çok yakın olduğu görülmüştür.

- İşletmelerin büyük bir bölümü projelerinin satış fiyatını belirlerken hala klasik maliyet + kar yöntemini kullanmaktadır ikinci aşamada ise geçmiş deneyimlerinden yararlanmaktadır. Bu noktada işletmelerin günümüzün zorunlu kıldığı rakipleri takip etme ve müşterilerin isteklerini dikkate alma gibi konulara hala önem göstermediği söylenebilir.

- İşletmeler yeterli düzeyde pazar araştırması yaptıklarını belirtirken, bu araştırmayı da projenin tasarımı başlamadan önce gerçekleştirdiklerini belirtmişlerdir. Ayrıca işletmeler tedarikçi ve satışa aracılık eden pazarlama kuruluşlarından da geri bildirimler alarak projelerinin tasarımında bu bilgileri kullandıklarına dikkat çekmişlerdir.

- Literatürde ürün maliyetlerinin \%70-80'inin ürünün henüz tasarım aşamasında oluştuğunu ve üretim başladıktan sonra maliyet azaltma çabalarının işletmeler için yeterli düzeyde getiri sağlamayacağ tasarım aşamasında maliyet düşürme faaliyetlerinde bulunduklarını belirtirken, önemli bir kısmı da proje esnasında maliyetleri düşürmeye çalıştıklarını belirtmiştir.

- İşletmelerde yer alan tüm bölümlerin maliyetlerin belirlenmesi ve azaltımı çabalarına katılımı maliyet yönetimine geniş kapsamlı katılım gereğinin bir göstergesidir. Mühendis, mimar, lojistik işlerinde çalışan elemanların ve özellikle tedarikçilerin de bu sürece katılmaları işletmelerce sağlanmıştır.

- İnşaat sektöründe alt yüklenicilerle çalışmak oldukça yaygındır. İşletmeler yüksek oranlarda alt yüklenicileri ve tedarikçileri ile sürekli koordinasyon halinde olduklarını, onlara maliyet hedefleri verdiklerini, yaptıkları faaliyetler nedeniyle maliyetlerde düşme yaşanırsa bunu onlarla paylaştıkları ve alt yüklenicilere eğitim verdiklerini belirtmişlerdir. 
- İşletmelerin yeni bir maliyet yönetim tekniğini kullanmalarında öncelikle teknolojik gelişmeler, ikinci olarak maliyet odaklı olmaları ve rekabetin şiddeti, daha sonra ise çevresel değişimler ile rakiplerin sayısı gelmektedir. Bu sıralamaya baktığımızda işletmelerin yeni maliyet yönetimi tekniklerini kullanırken öncelikle içsel faktörlerden etkilendikleri daha sonra ise dışsal faktörlerin geldiği açıktır.

- İşletmelerin önemli bir bölümünün projelerin öngörülen maliyetlerinin artması durumunda ilk seçenek olarak satış fiyatlarını artırmayı seçtikleri belirlenmiştir. İkinci aşamada işletmelerin önemli bir bölümünün alt yüklenici ve tedarikçilerle uzun dönemli anlaşmalar yaparak maliyetleri azaltma yoluna gittikleri ve son olarak kar marjlarını azaltmayı bile kabul ettikleri belirlenmiştir. İşletmelerin proje kalitesinde ve özelliklerinde azalmayı tercih etmedikleri dikkat çekmektedir.

Çalışmamız sonucunda elde edilen bulgular işletmelerin halen yeni maliyet yönetim teknikleri hakkında yeterli bilgilere sahip olmadıkları ve fiyatlandırma aşamasında maliyet + kar yöntemini kullandıkları sonucuna varılmıştır. İşletmelere, yeni maliyet yönetimi teknikleri ve işletmelerde etkin muhasebe sistemlerinin kurulması konusunda mali danışmanlardan destek almaları önerilmektedir. Özellikle yurtdışında faaliyet gösteren işletmelerin artan rekabet koşullarında varlıklarını sürdürebilmeleri için tedarikçileri ve alt yüklenicileri ile birlikte uzun süreli çalışmayı ilke edinmeleri, maliyetlerin aşılması durumunda ilk seçenek olarak satı̧̧ fiyatını artırmak yerine maliyetleri azaltabilecek diğer seçeneklere yoğunlaşmaları önem arz etmektedir. Satış fiyatının hatalı belirlenmesi işletmeler için satış yapamama, satış için uzun süre bekleme, dolayısıyla gelir sağlayamama, gelir-gider dengesinin ciddi şekilde bozulması gibi olumsuzluklara yol açabileceği için işletmelerimizin bu konuya daha dikkatli yaklaşmaları gerektiği düşünülmektedir. 


\section{KAYNAKÇA}

AHMADOV, T., (2006). Stratejik Maliyet Yönetiminin Bir Enstrümanı Olarak Hedef Maliyetleme Yöntemi ve Mobilya Sektöründe Uygulanabilirliği Üzerine Bir Araştırma, (Yayınlanmamış Yüksek Lisans Tezi), Niğde Üniversitesi /Sosyal Bilimler Enstitüsü, Niğde.

ALAGÖZ, A. ve CERAN, Y., (2006). Stratejik Maliyet ve Kar Planlama Aracı Olarak Hedef Maliyet Yöntemi (Target Cost Management), Selçuk Üniversitesi Sosyal Bilimler Enstitüsü Dergisi, 15, 61-83.

ALP, G., (2010). İnşaat İşletmelerinde Stratejik Planlama ve Kaynak Tabanlı Bakış Açısına Uygunluk Üzerine Anket Çalışması, (Yayınlanmamış Yüksek Lisans Tezi), İstanbul Teknik Üniversitesi /Fen Bilimleri Enstitüsü, İstanbul.

AX, C. and GREVE, J. and NILSSON, U., (2008). The Impact of Competition and Uncertainty on the Adoption of Target Costing. International Journal Of Production Economics, 115, 92-103.

BARFIELD, J.T. and RAIBORN, C.A. and KINNEY, M.R., (2000). Cost Accounting. Ohio:South Western College Publishing Co.

BOZDEMIR E. ve ORHAN M. S., (2011). Maliyet Kontrol Arac1 Olarak Hedef Maliyetleme Yönteminin Türk Otomotiv Sanayinde Uygulanabilirlik Düzeyinin İncelenmesi, Atatürk Üniversitesi İktisadi ve İdari Bilimler Dergisi, 2, 163-179.

BRIMSON, J.A., (1991). Activity Accounting: An Activity Based Costing Approach. New York: John Wiley and Sons.

CHAN, D.W.M. and CHAN, A.P.C. and LAM, P.T.I. and WONG, J.M.W., (2011). An Empirical Survey of The Motives and Benefits of Adopting Guaranteed Maximum Price and Target Cost Contracts in Construction, International Journal of Project Management, 29, 577-590.

COŞKUN, A., (2008). Hedef Maliyetleme ve Uşak İli Battaniye Üretim İşletmelerinde Uygulanabilirliği Üzerine Bir Araştırma. (Yayınlanmamış Yükseklisans Tezi), Afyon Kocatepe Üniversitesi/Sosyal Bilimler Enstitüsü, Afyonkarahisar.

DESS Gregory G. and DAVIS Peter S., (1984), "Porter's (1980) Generic Strategies as Determinants of Strategic Group Membership and Organizational Performance", Academy of Management Journal, Vol:27, No: 3, 467-488.

EKİNCİ, M.B., (2006). Türkiye'nin Mukayeseli Üstünlüğe Sahip Olduğu Hizmet Alt Sektörlerinden İnşaat: Sorunlar ve İmkanlar, Celal Bayar Üniversitesi İktisadi İdari Bilimler Fakültesi Yönetim ve Ekonomi Dergisi, 1, 61-78.

ELLRAM, L.M. ve STANLEY, L.L., (2008). Integrating Strategic Cost Management With Environment: Strategies, Practices and Benefits. Journal of Purchasing Supply Management, 14, 180-191

ERDEN, S.A., (1997). İnşaat Taahhüt İşleri ve Muhasebesi, Isparta: Beta

GÖKTÜRK, İ., (2007). İnşaat Sektöründe Fizibilite Aşamasında Maliyet Tahmini Yapmakta Karşılaşılan Zorluklar ve Çözüm Önerileri Üzerine Bir Değerlendirme, 
(Yayınlanmamış Yüksek Lisans Tezi), İstanbul Teknik Üniversitesi/ Fen Bilimleri Enstitüsü, İstanbul.

GRUNDY, T., (1996). Strategic Business Finance Using Finance For Strategic Advantage, London: Kogan.

GÜNDÜZ, H.E.,(1997). Dünya Klasındaki İşletmelerde Bir Maliyet Yönetim Aracı Olarak Faaliyetlere Dayalı Maliyet Sistemi ve Bir Uygulama, Ankara: Tisamat.

IBUSUKI, U. and KAMINSKI, P. C., (2007), Product Development Process with Focus on Value Engineering and Target Costing: A Case Study in an Automotive Company. International Journal of Economics, 105, 459-474.

KARAA, E. ve GEYIKCÇİ, U.B., (2015), Analitik A ğ Süreci ile Lojistik Sektöründe Lojistik Maliyet Unsurları ve Ağırlıklarının Belirlenmesi, Süleyman Demirel Üniversitesi İktisadi ve İdari Bilimler Fakültesi Dergisi, 1,101-113.

KARCIOĞLU, R., (2000). Stratejik Maliyet Yönetimi Maliyet ve Yönetim Muhasebesinde Yeni Yaklaşımlar, İstanbul: Aktif.

KOÇSOY, M.,(2008). Hedef Maliyetleme ve Türk İmalat İşletmelerinde Uygulanması, (Yayınlanmamış Doktora Tezi), Ankara Üniversitesi/Sosyal Bilimler Enstitüsü, Ankara.

OCAKÇI, A., (2007). İnşaat İşletmelerinde Maliyet Kontrol Aracı Olarak Esnek Bütçeleme ve Bir Uygulama, (Yayınlanmamış Yüksek Lisans Tezi), İstanbul Teknik Üniversitesi/Fen Bilimleri Enstitüsü, İstanbul.

SAVAŞ O., (2003). Hedef Maliyet Yönetim Sisteminin Başarısını Etkileyen Faktörler Üzerine Türk Hazır Giyim Sektöründe Bir Araştırma, Erciyes Üniversitesi İktisadi ve İdari Bilimler Fakültesi Dergisi, 20, 183-201.

SOBOTKA, A. and CZARNIGOWSKA, A., (2007). Target Costing in Public Construction Projects, 9th International Conference On Modern Building Materials, Structures, And Tecniques, Vilnius.

YÜZBAŞIOĞLU, N., (2004). İşletmelerde Stratejik Yönetim ve Planlama Açısından Stratejik Maliyet Yönetimi ve Enstrümanları, Selçuk Üniversitesi Sosyal Bilimler Dergisi, 12, 387- 411.

http://www.enka.com/Pdf/2014_ENR-Top-250-International-Contractors-List.pdf (Erişim tarihi: 10.09.2017)

http://intes.org.tr/content/Mart-2014.pdf (Erişim tarihi: 10.09.2017) 